\title{
Morphological Analysis of Slang Words Spoken by Transgender Community in Manado
}

\author{
$1^{\text {st }}$ Nurmin F.R. Samola \\ Faculty of English Education \\ Universitas Negeri Manado \\ Manado, Indonesia \\ nurminsamola@unima.ac.id \\ $4^{\text {th }}$ Rinny S. Rorimpandey \\ English Education Department \\ Universitas Negeri Manado \\ Manado, Indonesia \\ rinnyrorimpandey@unima.ac.id
}

\author{
$2^{\text {nd }}$ Fivy A. Andries \\ English Education Department \\ Universitas Negeri Manado \\ Manado, Indonesia \\ fivyandries@unima.ac.id
}

\author{
$3^{\text {rd }}$ Tirza A. Kumayas English \\ Education Department Universitas \\ Negeri Manado \\ Manado, Indonesia \\ tirzakumayas@unima.ac.id
}

\begin{abstract}
The purpose of this research is to describe slang words spoken by transgender community in Manado, to describe the meaning and how they form the slang words. This is a descriptive qualitative research. The data were taken from natural conversation among transgenders and the data taken were in the form of oral sentences. The source of data was transgender community in Manado city. The results of the study shows that transgender slang words are formed by borrowing words of foreign language or syllables of Indonesian language, using additional deviated words with specific affixes, or changing of phonemes or into other common words. Transgender community inserts the slang words into Manado Malay language using Manado Malay language structure to form their utterances. They sometimes use it as a secret code and show solidarity marker among their community.
\end{abstract}

Keywords-Morphological analysis, Slang Words, Transgender Community

\section{INTRODUCTION}

It seems that language has been improving in use and progress. They influence the use of language specifically vocabulary of the language including Manado Malay words. Some of them are new words but they have meaning shift. Certain people call them as a slang words. The majority of people use slang as social and ethnic identifier to reinforce power or status. Sometimes slang is used by particular group of people as speech community.

Every speech community speaks their own form or variety of language for the communication goes smoothly. One of them is the transgender community who use slang words more often in their conversations. The member of this group is considered minority in society but the number is growing day by day, especially in big cities. The transgender communities are generally unique and exclusive because their code is the result of their creativity in language producing new forms or words which are different from common language spoken. They usually have specific code which is known as slang. It is created arbitrarily. It is difficult to explain the reason why they create new words and mostly as deviating away from standard language. They use the slang exclusively, only understood by members of the group since it is only for internal communication. This might be the reason why the slang words are always changing. Sometimes slang word is more attractive and expressive than standard language.

Kridalaksana (2008:156)[1] states that slang is a variety of language, it is not official, used by young people or particular social group for internal communications in order to make people in other group do not understand, formed in new vocabulary and always changing. Meanwhile, according to Chaer and Agustina (1995:87-88)[2], as the secret and special social variation, slang can only be understood by certain people in a limited area and may not be known by the people outside the group. Soeparno (2002:73)[3] argues that slang is a manifestation or realization of the language that is specific and secret. Specific means used by certain groups that is very limited. Secret means people outside their group should not understand. As a step to maintain the confidentiality, slang is always modified or changed, so it is temporal. Therefore, the words used as slang seem increase everyday since it always changes. Slang emphasizes more on vocabulary than the phonology or grammar. Slang is temporal. According to Keraf (2009:108-109)[4], slang word is a kind of a pure or high conversation word. Slang consists of words that are nonstandard and informal and created exclusively.

Regardless of social position, almost all people especially young people as well as transgender community use slang and colloquial from time to time. According to Fromkin and Rodman (2018:264)[5], slang is considered as a result of the development of the new words that happen as 
a creative expression from people to make the words more efficient and simpler to be uttered. Slang words vary from generation to generation and from one geographical area to others. Thus, the existence of slang is never constant. The form of slang and colloquial words occur through some processes.

Linguistically, these processes are called word formation processes. Word formation processes are the processes of creating new words and the new uses of the old words. For example, in daily communication, the term KEPO is often used. It is formed by the process of acronym, in which it is actually derived from Knowing Every Particular Object. Slang is the non-standard use of words in a language and it is categorized as a part of language in a society. According to Fromkin \& Rodman (2018:264)[5], slang is a kind of casual language that occurs as a result of the rapid growth of new words that is used as a creative expression from people in order to make the words more efficient and simpler to be uttered. They also state that there are several functions of slang, they are: (1). Slang is used as solidarity makes, and also it is used to identify people as those who belong to the group members. (2). Slang is used to show intimacy among users.

\section{RESEARCH METHOD}

This research used descriptive qualitative research. Sudaryanto (1992:62)[6] argues that the term of descriptive has relation with language study "descriptive linguistic". It is a study based on facts or phenomena empirically exists on the speakers, so the result or noted in form of language used. So it is like portraits (explain as they are). The data source of the study is transgender community in Manado. The objects of this study are slang words, phrases, sentences. To collect the data, the researcher observed and interviewed the transgender community using recording technique. The writer did an interview with the members of transgender community in Manado to get information about slang words. According to Moleong (2011:186)[7], interview is a conversation with a certain purpose.

\section{RESULTS AND DISCUSSION}

The writer analyzed the slang words found in the conversation among transgenders. The writer analyzed the word formation found in the conversation. It consists of clipping, acronym, blending, back formation, and deleting. Then, the writer described the the process of forming the slang words.

\section{A. The Word Formation of Slang Words}

There were 25 data collected in this research and the data were analyzed based on the types of word formation, then followed by explaining the meaning of the new words formed.

\section{Clipping}

Clipping is a process of reducing the element of word to make the word becomes shorter without changing the meaning. However, Latif et al., (2001) put forward that there are six kinds of clipping processes: 1) cutting off the back part of the word, 2) cutting off the front part of the word, 3) cutting of the front and back parts of the word, 4) cutting of the back part of a word and replacing it with certain sounds, 5) cutting off the back part of a word and replacing it with certain new spelling, 6) clipping wihch are related to one's name. The writer found some words dealing with the process of clipping.

\section{Datum 1}

Ceps (noun) is from the word cap tikus (alcoholic drink). This word is formed by changing the letter -a- with -e- in the word cap and deleting all letters of the second word by replacing it with the letter -s-.

Suka skelong mo minum ceps eike noh I really like to drink cap tikus)

\section{Datum 2}

Is Dahlia ( noun) refers to a name which means Islam (Moslem). This word is formed by cutting off the back part of the word or the second syllable of the word and replacing it with another new spelling of word.

\section{Datum 3}

Krisdayanti ( noun) refers to an artist's name which means Kristen (Christian). This word is created by cutting off the back part or the second syllable of the word and replacing it with other new spelling of word.

The words are used as what can be seen the following sentence:

Deyes Is Dahlia ato Krisdayanti?

'Is she/he Moslem or Christian?'

\section{Datum 4}

Lapangan (noun) refers to the word lapar (hungry). The transgenders use this word to say if they are hungry. This is a new slang word formed by cutting the last letter and replacing it with certain letters or spelling. This word is really deviated away from the target word since they have a very different meaning. Lapangan means a field or range of activity.

So lapangan eike

'I am hungry'

\section{Datum 5}

Kencana (noun) is word meaning gold. This is used by transgenders in their conversation to say the word urinate. This word is said to replace the word kencing (urinate). The word is formed by deleting the letters -ing- in the word kencing and replacing them with other letters -anaas in kencana.

Tunggu ndak lambretta eike mo cus kencana dulceng 'Wait a moment I want to urinate'

\section{Datum 6}

Capung (adjective) means capek (adjective) tired. They create a new word. The process of creating the word is deleting the letters -ek- in the word capek are replaced by -ung- and it becomes capung.

So capung eike mo ba res dulceng ndak lama

'I'm tired, I want to take a rest for some minutes'

\section{Datum 7}

Macica (noun) refers to the word macis 'korek' in English 'match'. This word is originated 
from Manado Malay word "macis" (noun) created by changing the last letter - s with - ca.

Yei edes macica?

'Do you have match?'

\section{B. Acronym}

Acronym is the process by forming new words from the initial letters of a set of other word.

Acronym is another kind of abbreviation. There are two kinds of abbreviation, they are: Initialism and Acronym. Intialism is a type of abbreviation formed by the initial letters of the words and pronouncing them by spelling each letter, for example: UN for United Nations. Whereas acronym itself is formed by taking the initial letters of some or all of the words in a phrase or title and pronouncing them as a word, for example: NATO for North Atlantic Treaty Organization. Sometimes this word is deviated away to other meaning with No Action Talk Only. The example of the data indicating acronym can be seen in the following:

\section{Datum 8}

Kepes is originated from the acronym KEPO. They create this word by changing the final letter $-\mathrm{O}$ with -es. The slang word can be seen in the following sentence:

Yei pe kepes skelong

'You are eager to know something'

\section{Blending}

A blending is a combination of the parts of two or more words, usually the beginning of one word and the end of another. Only one data found dealing with blending process.

\section{Datum 9}

Capcus (noun) is from the word cap tikus (Manado Malay) a traditional alcoholic drink. This word is formed by combining the two words taking the whole of the first word and the end of another word by replacing the letter -k- with -c- in the second word.

Suka skelong mo minum capcus eike noh

'I really like to drink cap tikus'

\section{Borrowing}

This word formation means that the slang word is taken from another language because the creation of slang is not limited to the speaker's or researcher's own language. The transgender community in Manado has adopted a numbers of loan words from other language such as Dutch, English and others.

\section{Datum 10}

Youngen (noun) refers to cowok 'young man'. This word is derived from Dutch and they take it without any changes of the word.

\section{Datum 11}

Meises (noun) cewek 'girl' is an arbitrary word created by creativity and cleverness

Pe cantik tu meises sana
'She's a beautiful girl'

\section{Datum 12}

Nit (particle) is derived from Dutch word 'not' (adverb) without any changes of the word. They take the whole word and use in their daily conversation.

Nit, deyes ndak suka pa yei

'No, she/he doesn't like you'

\section{Datum 13}

Yei (pronoun) kamu 'you' is taken from Dutch word without any changes of the word. They take the whole word and they use it in their conversation.

Yei pe rambutan dapa lia pe moiten skelong

'Your hair looks good'

\section{Datum 14}

Eike (pronoun) saya 'I or me' is taken from the original word of Dutch "Ik" (pronoun) that means 'me or I'. Eike pe yongen moiten skelong doe 'My boyfriend is handsome'

\section{Datum 15}

Eyes (particle) ya 'yes'- derived from an affirmative particle in English language 'yes' (particle) by adding a letter -e in front of the word.

Eyes, eike mo cus Manado

'Yes, I'm going to Manado'

\section{Datum 16}

Helte (noun) uang 'money' is originated from the word "halte" (bus stop) transformed by changing the letter -a to e

Nit edes helte eike

'I don't have money'

\section{Datum 17}

Keken (verb) melihat 'look' is originated form the word keker (noun) that means a 'binocular', transformed by changing the last letter $-\mathrm{r}$ to $-\mathrm{n}$.

Mari jo torang pi ba keken yongen di sana

'Let's look for some boys there'

\section{E. Coinage}

Coinage is the invention of totally a new word in which that new word is created either deliberately or accidently and invented in the names of company's product. In this case, the typical process of coinage usually adopts the brand names of a product as common words.

\section{Datum 18}

Lambretta (noun) is the brand name of a line of motor scooter initially manufactured in Milan, Italy, by Innocenti. This word refers to an adjective lambat 'slow'.. The wor is transformed by deleting the two letters of the word -at and replacing them with the spelling -retta. This word is created so, probably because of the first syllable are similar, lama - lambretta and both has letter $-\mathrm{a}$ in the last syllable.

Kyapa lambretta skelong yei?

'Why are you so late?' 


\section{Datum 19}

Pantene (noun) is originated from word pantat 'ass'. This word is created by deleting the letters -at in the word pantat with the letters -ene- in the word pantene. The first syllable is similar, pantene - pantat

Robek yei pe calama dapa lia yei pe pantene

'Your pants is torn I can see your ass'

\section{Datum 20}

Pepsi (verb) pipis 'pee'. Pepsi is derived from word pipis, it is a product name (coinage word). Probably this word was created because of the pronounciation is quite similar, pepsipipis.

So rasa pepsi ini noh

'Feels like want to pee'

\section{Datum 21}

Panasonic (adjective) panas ' hot'. Panasonic itself is created from word panas it is a product name. This word was created because of the spelling and pronunciation of the first and second syllable is similar, panasonic - panas

Panasonic skali disini

'It's so hot here'

\section{Datum 22}

Motorola (noun) refers to the word motor 'bike'. This word is created to change the word motor. Motorola is a product name. This is used as slang word among transgenders probably because of the spelling and pronounciation of the first and the second syllable of the word is just the same, motorola - motor

Pe gaga ngana pe morotola doe

'Your bike looks awesome'

Slang words can be created by word formation. They are clipping, acronym, blending, the writer found several data, they are ceps, Is Dahlia, Krisdayanti, lapangan, kencana, capung, and macica. Clipping is a process that shortens a polysyllabic word by deleting one or more syllables and replacing with a certain spelling or phonemes.

Acronyms are formed by taking the initial letters of some or all of the words in a phrase or title and reading them as a word. The writer only found one slang word in this process, kepes.

Blends are words that are created from nonmorphemic parts of two already existing items. For this process there is only one data found, capcus.

Borrowing is the process of taking one word from another language because the creation of slang is not limited to the speaker's of the language. There are eight slang words found in this process: youngen, meises, nit, yei, eike, eyes, helte, keken.

Coinage is the invention of totally a new word in which that new word is created either deliberately or accidentally and invented in the names of company's product. There are five words found for this process: lambreta, pantene, pepsi, panasonic, motorola.

Allan and Burridge (2006)[8] confirm that there are six different slang types of the slang words as follow:

\section{1) Fresh and creative}

Fresh and creative means that slang words has totally new vocabulary, informal variety, cleverness, imagination, and it also can be an up to date words. Some words which are already familiar out mind possibly will be slang as we do not realize it. The reason why those slang become familiar in our mind because those slang appear in long time ago since slang are already appeared. The example is the slang word awesome. Awesome (adj) used that we think something is wonderful or amazing.

\section{2) Compounding}

Compounding means that slang language made by two words or more in which the words composed not correlated with denotative meaning. The example is big gun. It means a powerful person.

\section{3) Imitative}

Imitative means that the slang words imitating or derived from the Standard English Word, using the the Standard English Word in different meaning or combining two different words. The example is gonna. This is the slang words that derived from the phrase words 'going to'. The slang 'gonna' is commonly used by almost all people in the world.

\section{4) Blending}

A blend is the result from specific type of compounding, where several used into one in order to generate a new word. However, blending is typically accomplished by taking only the beginning of one word and joining it to the end of another word. The example are: motel (motor+hotel), infotainment (information+entertainment), smog (smoke+fog).

\section{5) Clipping}

Clipping type is one of variety of slang made by deleting of some parts of longer word become a shorter form in the same meaning. The example is the use of word 'exam' to mean 'examination'. The words which commonly used can be clipped into shorter form. In addition, clipping form is not appropriate to use in formal conversation.

\section{6) Coinage}

Coinage is the invention of totally a new word in which that new word is created either deliberately or accidentally and invented in the names of company's product, in this case, the typical process of coinage usually adopts the brand names of a product as common words.

\section{F. Transgender}

According to Atmojo (1986:2)[9], in general, transgender is a man who dresses and acts as women. Fassinger and Arseneau in Bieschke (2007:22)[10] argues that the transgenders are people who have gendervariant or gender-"transgressive". They express their gender in a different way from the appropriate behaviors and acts based on their (perceived) biological sex. Meanwhile, Cook (2004:7)[11] defines a transgender as persons who strongly identify themselves with the opposite sex. Yustinus (2006:81-82)[12] states, psychologically, the transgenders are included in gender identity disorder. He describes that gender identity is the individual subjective feelings about being a man or a woman. Most individuals have a gender identity in accordance with identification of physiological 
sex but there are some exceptions. For example, a person may have a penis, has all the features of secondary male sex (eg, high voice and mustache) and play the traditional role of men in public, but may feel that he is actually a woman. If there are incompatibilities between the identification of physiological sex of individuals with gender identity, the individual diagnosed as having gender identity disorder.

\section{CONCLUSION}

After having discussed the slang words spoken by the transgender community in Manado City, it may be concluded that the members of this community are very proud of their own condition by maintaining solidarity among them, showing that they belong to a unique community from the way they behave, act and speak. Speaking an uncommon language is one of the habits in their interaction and communication. They use slang words most of the time as to hide something from the listeners who do not belong to this group. However, they are some words used to euphemize the taboo words for it is not supposed to say for the sake of politeness. The way they create slang words is really arbitrary, they tend to play words by their own way showing their creativity. Most of the words are formed by deleting or changing certain letters then adding other letters or spelling and sometimes resulting in such deviated words.

\section{ACKNOWLEDGMENT}

It is a good moment for the writer to express gratitude to many parties who have already given her opportunity to develop knowledge of linguistics by conducting research. She acknowledges the Rector of Manado State University and LPPM UNIMA that facilitating her in having some fund for the continuation of improving the performance of UNIMA as well as the writer to keep doing research and publication.

\section{REFERENCES}

[1] H. Kridalaksana, Kamus Linguistik. Jakarta: PT Gramedia, 2008.

[2] L. Agustina and A. Chaer, "Sosiolinguistik Perkenalan Awal," Jakarta: Rineka Cipta, 2004.

[3] Soeparno, Dasar-Dasar Linguistik Umum. Yogyakarta: PT Tiara Wacana, 2002.

[4] G. Keraf, Diksi dan gaya bahasa. Jakarta: Gramedia Pustaka Utama, 2009.

[5] V. Fromkin, R. Rodman, and N. Hyams, An introduction to language. Cengage Learning, 2018.

[6] Sudaryanto, Metode Linguistik. Yogyakarta: Gadjah Mada University Press, 1992.

[7] L. J. Moleong, Metodologi Penelitian Kualitatif. Bandung: Remaja Rosdakarya, 2011.

[8] K. Allan and K. Burridge, Forbidden Words: Taboo and the Censoring of Language. New York: Cambridge University Press, 2006.

[9] K. Atmojo, Kami Bukan Lelaki. Jakarta: Pustaka Grafitipers, 1986.

[10] K. J. Bieschke, R. M. Perez, and K. A. DeBord, Handbook of counseling and psychotherapy with lesbian, gay, bisexual, and transgender clients. American Psychological Association, 2007.

[11] K. J. Cook, "Gender identity disorder: A misunderstood diagnosis," 2004.

[12] S. Yustinus, Teori Kepribadian dan Terapi Psikoanalitik FREUD. Yogyakarta: Kanisius, 2006. 